\title{
Études/Inuit/Studies
}

ANGILIRQ, Paul Apak, Zacharias KUNUK, Norman COHN, Hervé PANIAQ, Pauloosie QULITALIK, Bernard SALADIN D'ANGLURE, ISUMA PRODUCTIONS, 2002 AtanarjuatThe Fast Runner, Igloolik, Isuma Publishing, and Vancouver Coach House Books, 240 pages.

\section{Mick Mallon}

Volume 28, numéro 1, 2004

Art et représentation

Art and representation

URI : https://id.erudit.org/iderudit/012647ar

DOI : https://doi.org/10.7202/012647ar

Aller au sommaire du numéro

\section{Éditeur(s)}

Association Inuksiutiit Katimajiit Inc.

\section{ISSN}

0701-1008 (imprimé)

1708-5268 (numérique)

Découvrir la revue

Citer ce compte rendu

Mallon, M. (2004). Compte rendu de [ANGILIRQ, Paul Apak, Zacharias KUNUK, Norman COHN, Hervé PANIAQ, Pauloosie QULITALIK, Bernard SALADIN

D'ANGLURE, ISUMA PRODUCTIONS, 2002 AtanarjuatThe Fast Runner, Igloolik, Isuma Publishing, and Vancouver Coach House Books, 240 pages.]

Études/Inuit/Studies, 28(1), 185-186. https://doi.org/10.7202/012647ar 


\title{
Recensions / Book reviews
}

\author{
ANGILIRQ, Paul Apak, Zacharias KUNUK, Norman COHN, Hervé PANIAQ, \\ Pauloosie QULITALIK, Bernard SALADIN D'ANGLURE, ISUMA PRODUCTIONS \\ 2002 Atanarjuat The Fast Runner, Igloolik, Isuma Publishing, and Vancouver \\ Coach House Books, 240 pages.
}

From the time that it won the Caméra d'Or at the Cannes Film Festival in 2001, the film Atanarjuat has been that rare creature, a Canadian film that has gained international recognition. It has created its own place in the history of film, and will be studied by generations of enthusiasts in places remote from the Arctic. Even more exciting, it is a film that is indigenous in concept, and largely indigenous in creation. It is not only a record of a threatened culture, it may also be a potent force in its survival and regeneration.

Now a book has been published with the screenplay, lavishly illustrated by stills from the movie and illustrations from explorers' journals dating back nearly two centuries. In addition there is an illuminating ethnological commentary by Professor Bernard Saladin d'Anglure of Laval University. There is more: interviews with the director, comments by noted anthropological and cultural figures, and, the entire text is bilingual; Inuktitut and English. I won't review the book in terms of the history of film, important though that may be. I am more concerned with its active cultural importance. Some of my comments are pale rephrasings of those by Saladin d'Anglure in his section of the book. Others are my own, those of a worker in the field of the Inuktitut language.

The plot of the movie follows closely, but not exactly, the outline of an Inuit story based apparently on historical events. The heroes are two brothers, sons of an unskillful hunter ridiculed by those more competent who provide his family with food when his efforts are inadequate. They grow up to be successful, but in a feud with another group they are attacked while sleeping in a tent. The oldest is killed, the younger escapes by running naked across the ice. Later, he returns to seek vengeance. That is the outline of the story. There are several versions, depending on which story-teller gives it. The young Inuit of Isuma Productions, Inuit film-makers who for some years have been producing cultural documentaries in Igloolik, were fascinated by the tale, and produced the movie. Paul Angilirq, who died in 1998 of cancer, was the driving force, aided by the Qallunaaq Norman Cohn, and succeeded by Zacharias Kunuk.

That is the bare outline. Left like that, you have simply a stirring tale of hate, betrayal and revenge. In a culture that, like the rest of the world, is beset by Hollywood's formulas and Hollywood's heroes, Atanarjuat would be a home-grown drama that would strengthen a threatened sense of identity. It is a loving and precise attempt to recreate the past: the clothing, the hunting practices, the beliefs, the visceral

ETUDES/INUIT/STUDIES, 2004, 28(1): 185-210 
pleasure of life on a beautiful but demanding landscape ${ }^{1}$. But Atanarjuat also has a thread of shamanism running through it. There is an amulet, the physical embodiment of a force of evil that has taken root in the small community. The humans are more than the sum of their individual virtues or vices. There is something deeper at work. Saladin d'Anglure has been studying shamanism for years. He sees the film as part of the search to recover the spiritual component of traditional life, a component that was crushed by the arrival of missionaries. It would be wrong, however, to see this as an attempt simply to return to the past. There are modern Inuit who want to reconcile the two traditions that they have inherited. So the climax of the thriller veers away from the traditional ending, one that would be expected also of Clint Eastwood, Schwarzenegger and company. This is not simply an ancient tale, nor a Iglooliwood thriller.

I have dwelt on the movie at such length because of course the book is its reflection. There is the screenplay laid out, with the addition of the comments on the motivations and reactions of the characters. One could argue that if the movie is well made, the motivations and reactions do not need a retelling in print. Yes, but it is intriguing to see it spelled out, and in the case of the shamanistic scene at the beginning of the film, I must admit I was confused about what exactly was going on.

I would like to finish the review by a change of perspective. This is a book. I see it as a tool for language learning, not just for the few Qallunaat who desperately want to learn more about this unique and threatened language, but also for many Inuit. There are those who have lost, or never acquired full command of the language. The book is bilingual. It is not laid out in two sections. The English and Inuktitut are on facing pages, which should make it easier to compare the two texts. But artistic decisions on layout (and Stan Bevington of Coach House Books has done a beautiful job) have affected the symmetry of the language section. The Inuktitut text on the left does not match its English version on the right. An unintrusive numbering system would have helped. There would still be the problem that, as with French and English, one language requires more space than the other, but a judicious positioning of illustrations could solve that problem. There is another point to make. The Inuktitut is in syllabics: that makes sense in the Keewatin and Baffin regions, and in Nunavik. But in Canada there are Inuvialuit, Qitirmiut and Labradoreans who do not use syllabics, and also Alaskans and Greenlanders beyond our borders. Maybe I should get Isuma's blessing to encourage a young Inuk to apply for a grant to produce a Romanized version...

A tiny final fussy note, on a point mentioned in a footnote by Saladin d'Anglure. The pronunciation of the name Atanarjuat has a long vowel in the third syllable. The correct spelling is Atanaarjuat. Ah well, once a schoolteacher always a schoolteacher.

\author{
Mick Mallon \\ P.O. Box 2014 \\ Iqaluit, Nunavut \\ Canada, XOA OHO \\ ittukuluk@yahoo.ca
}

Parenthetically, however, it was disappointing to see Atanarjuat handle his kayak with the same Qallunaaq paddle-waving clumsiness that had me laughed at 33 years earlier in Povungnituk.

\title{
186/RECENSIONS
}

